\title{
Bu Fei Decoction attenuates the tumor associated macrophage stimulated proliferation, migration, invasion and immunosuppression of non-small cell lung cancer, partially via IL-10 and PD-L1 regulation
}

\author{
LINA PANG $^{1,2}$, SHUYAN HAN ${ }^{1,2}$, YANNA JIAO ${ }^{1,2}$, SHANTONG JIANG $^{1,2}$, XIRAN HE ${ }^{1,2}$ and PINGPING LI ${ }^{1,2}$ \\ ${ }^{1}$ Key Laboratory of Carcinogenesis and Translational Research (Ministry of Education), \\ Peking University Cancer Hospital and Institute; ${ }^{2}$ Department of Integration of Chinese and \\ Western Medicine, Peking University School of Oncology, Beijing 100142, P.R. China
}

Received January 9, 2017; Accepted March 3, 2017

DOI: $10.3892 /$ ijo.2017.4014

\begin{abstract}
Macrophages play a pivotal role in tumor microenvironment. Bu-Fei Decoction (BFD) is a classical formula of traditional Chinese medicine (TCM) to alleviate lung cancer related symptoms, whether it has antitumor effect or could influence cancer microenvironment deserves further study. The aim of the present study was to examine the antitumor effect of BFD on non-small cell lung cancer (NSCLC), and to investigate the underlying mechanisms through tumor associated macrophages (TAMs). M2-polarized TAMs were induced by Phorbol 12-myristate 13-acetate (PMA) and interleukin 4 (IL-4). The antitumor activity of BFD in vitro was investigated in A549 and H1975 cells using MTT assay. The in vivo anticancer effect of BFD was evaluated in athymic nude mouse xenograft model. The invasive and migration properties of NSCLC cells were measured using Transwell. The protein expression was assessed using western blotting, ELISA and immunohistochemistry. The gene expression was examined using RT-PCR. TAMs was successfully established. Conditioned medium from TAMs increased cell proliferation, migration and invasion in NSCLC cells $(\mathrm{p}<0.05)$. BFD
\end{abstract}

Correspondence to: Professor Pingping Li, Key Laboratory of Carcinogenesis and Traditional Research (Ministry of Education), Peking University Cancer Hospital and Institute, 52 Fucheng Road, Beijing 100142, P.R. China

E-mail: lppmal@163.com

Abbreviations: TCM, traditional Chinese medicine; BFD, Bu-Fei Decoction; NSCLC, non-small cell lung cancer; TAMs, tumor associated macrophages; TAM-CM, tumor associated macrophageconditioned medium; IL-10, interleukin 10; PD-L1, programmed death ligand-1; PMA, phorbol 12-myristate 13-acetate; IL-4, interleukin 4

Key words: tumor associated macrophages, tumor microenvironment, non-small cell lung cancer, Bu Fei Decoction, IL-10, PD-L1 showed dose-dependent inhibitory effect on cell proliferation, migration and invasion abilities induced by TAMs. TAMs and rhIL-10 promoted the mRNA and protein expression of PD-L1 in NSCLC cells $(\mathrm{p}<0.01)$. Anti-IL-10 antibodies inhibited the elevated PD-L1 expression induced by TAMs. In vitro, the expression of PD-L1 and IL-10 was inhibited by BFD dosedependently. In vivo, BFD suppressed A549 and H1975 tumor growth and decreased the expression of IL-10, PD-L1 and CD206. The results showed that TAMs play an important role in tumor progression of NSCLC, which was associated with tumor proliferation, migration, invasion and immunosuppression. Moreover, the antitumor mechanism of BFD is related to interruption of the link between TAMs and cancer cells by inhibiting the expression of IL-10 and PD-L1 in vitro and in vivo. Our results demonstrated BFD's potential as a novel treatment for NSCLC.

\section{Introduction}

Lung cancer is the most frequently diagnosed cancer in men and the third most commonly diagnosed cancer in women throughout the world (1). Eighty to eighty-five percent of lung cancer are non-small cell lung cancer (NSCLCs) (2). The majority of lung cancer (57\%) are diagnosed at advanced stage. Despite decades of bench and clinical research to attempt to improve outcome for NSCLC, the 5-year overall rate remains only $21 \%$ (3). The existing therapies, including radiotherapy, chemotherapy and the emerging target therapy, are still unsatisfactory to improve outcomes for lung cancer patients (4). It is an urgent issue to achieve breakthrough in medical treatment on lung cancer.

Tumor microenvironment has attracted much attention in recent years. Macrophages are the main non-cancer cell components in tumor microenvironment, and often described as tumor-associated macrophages (TAMs) (5). Macrophages originate from blood monocytes, and there are two main classes of macrophages: classically activated macrophages (also called M1) and alternatively activated macrophages (M2) (6). When exposed to lipopolysaccharide (LPS) or 
interferon- $\gamma($ IFN- $\gamma)$, macrophages are polarized into M1 macrophages; whereas interleukin-4 (IL-4) or interleukin-13 (IL-13) exposure can polarize them into M2 macrophages (7). M1 macrophages generally exhibit microbicidal activity and have pro-inflammatory phenotype. In contrast, M2 macrophages are able to tune inflammatory responses and adaptive Th2 immunity (8). Solid tumors are often infiltrated with abundant macrophages, which resembles M2 macrophages that can produce high amounts of interleukin (IL)-10 and transforming growth factor- $\beta$ (TGF- $\beta$ ), express scavenger receptors (CD204) and mannose receptor (CD206), and exhibit anti-inflammatory and tissue repair functions (9).

TAMs play an essential role in the complex process for coevolution and tumorigenesis in tumor microenvironment. Lee et al showed that IL-10 mediated M2-polarized TAMs promoted renal cell carcinoma (RCC) growth through increasing BMP-6 expression (10). TLR4/IL-10 signaling increased the proliferation of cancer cells induced by M2-polarized TAMs, while TLR4 siRNA or neutralizing antibodies of TLR4 and IL-10 significantly reversed the increased growth (11). TAMs and their secreted cytokines (eg., IL-10, TNF- $\alpha$, TGF- $\beta$ ) or proteases were able to promote the migration and invasion of cancer cells in all aspects $(12,13)$. Previous studies revealed that M2-polarized macrophages induced migration and invasion of human basal carcinoma cells and prostate cancer cells $(14,15)$. TAMs also promoted tumor angiogenesis, proliferation and invasion in pancreatic cancer, and hepatocellular carcinoma (16-19). Indeed, removal of macrophages by genetic mutation, ablation of macrophage function or inhibition of macrophage infiltration into tumors successfully reduced tumor progression and metastasis in human breast carcinomas, and pulmonary metastatic cells $(20,21)$. The establishment of macrophages contributed to progress of research to develop therapies that specifically target macrophages. These possible therapeutics are divided into three main aspects: inhibition of monocyte recruitment into tumors, eradication of resident macrophages already in tumors, and neutralization of key molecules of TAM release, such as CCL5 and VEGF $(8,22-25)$. However, most of these therapeutic methods are still at the research stage.

In addition, IL-10 may promote cancer growth by suppressing macrophage function and enabling tumors to evade immunosurveillance (26). Kuang and his colleagues (27) observed that IL-10 secreted from activated monocytes strongly induced the expression of programmed cell death 1 (PD-L1) in an autocrine manner. PD-L1-positive monocytes induced $\mathrm{T}$ cell dysfunction, as defined by the presence of low cytotoxicity to tumor cells and a reduction in $\mathrm{T}$ cell proliferation targeted therapy aiming at IL-10 or PD-L1 may be an effective method for NSCLC. Whether IL-10 secreted from TAMs could regulate the expression of PD-L1 in NSCLC cells by paracrine way and weather BFD can interfere with the interaction between TAMs and tumor cells is still unknown.

Bu Fei decoction (BFD) is a classical formula of traditional Chinese medicine (TCM) in clinical setting for hundreds of years. It consists of six herbal Chinese medicines including Codonopsis pilosula, Schisandra chinensis, Rehmannia glutinosa, Astragalus, Aster and Cortex Mori. BFD is a mixture of these herbal Chinese medicines in a certain proportion. BFD is widely used for improving lung functions, especially for the $Q i$ deficiency. So it is to alleviate lung cancer related symptoms in oncology clinical context and has a good clinical effect. The team of Xia et al $(28,29)$ have devoted research effort on BFD on lung tissue of pulmonary fibrosis. They found that BFD could decrease the degree of alveolitis and pulmonary fibrosis decreased significantly, which was associated with reduced expression of $\alpha$-SMA, MMP-9 and TIMP-1 and re-established the balance among these, then improved the abnormal metabolism of extracellular matrix. Nevertheless, there has been until now no systematic research to study BFD as a whole in lung cancer. In recent years, several studies found that many components of BFD possess antitumor effect. Research data showed that herbal extract from Astragalus could induce dendritic cell maturation, promote IFN- $\gamma$ secretion and activate the antitumor effect of special cytotoxic $\mathrm{T}$ lymphocytes (CTLs) (30). Some research data show that Schisandrin B, one of the bioactive compounds from Schisandra chinensis, could suppress epithelial mesenchymal transform (EMT) in breast cancer both in vitro and in vivo, scavenged oxygen free radicals and inhibited the expression of VEGF $(31,32)$. However, nothing is known on whether BFD possesses antitumor effect or it could influence tumor microenvironment in lung cancer. Therefore, the aim of the present study was to investigate the effects of BFD on TAMs and NSCLC in vitro and in vivo, to possible clarify underlying mechanisms.

\section{Materials and methods}

Preparation of drugs. The component herbs of BFD used in this study are as follows, Codonopsis pilosula, Schisandrachinensis, Rehmannia glutinosa, Astragalus, Aster and Cortex Mori, at a ratio of 3:2:1.8:4:2:2. Furthermore, Schisandra chinensis was treated with vinegar. Radix Rehmanniae Praeparata was used in the prescription. Aster is a honey-fried Chinese herb. The BFD granules used in the present study were purchased from Beijing Tcmages Pharmaceutical Co., Ltd. (Beijing, China). The quality of formula granules was monitored by Fourier transform infrared spectroscopy (FTIR) (Model IRPRestige-21; Shiamdzu Corp., Kyoto, Japan). Prior to experiment, the formula granules were milled to powders and dissolved in distilled water to get a concentration of $1 \mathrm{~g} / \mathrm{ml}$ crude drug, and then filtered through a $0.22-\mu \mathrm{m}$ membrane (Millipore, Billerica, MA, USA). The concentrations of BFD in the study refer to the crude drug concentrations.

Reagents. Phorbol 12-myristate 13-acetate (PMA) and 3-(4, 5-dimethyl-2-thiazolyl)-2, 5-diphenyl-2-H-tetrazolium bromide (MTT) was purchased from Sigma-Aldrich (St. Louis, MO, USA). Recombinant human IL-4 was purchased from R\&D Systems (Minneapolis, MN, USA). Human $\mathrm{Fc}$ receptor binding inhibitor purified and antihuman IL-10 for neutralization were purchased from eBioscience (San Diego, CA, USA). Recombinant human IL-10 was purchased from Peprotech (Rocky Hill, NJ, USA). Antibodies and their respective sources were as follows: anti FITC mouse anti-human CD206 antibody (BD Pharmingen, 551135), anti-mannose receptor antibody (Abcam, ab64693), anti-PD-L1 antibody (Abcam, ab58810), anti-IL-10 antibody (Abcam, ab9969). 
Cell culture and differentiation. Human NSCLC cell lines A549 and NCI-H1975 were purchased from the American Type Culture Collection (Manassas, VA, USA). Human monocytic leukemia U937 cells (RIKEN, RCB0435) were donated by Professor C. Wang, Peking University Health Science Center. Cells were maintained in RPMI-1640 supplemented with $10 \%$ fetal bovine serum (FBS) (Gibco), $100 \mathrm{U} / \mathrm{ml}$ penicillin, and $100 \mu \mathrm{g} / \mathrm{ml}$ streptomycin at $37^{\circ} \mathrm{C}$ and $5 \% \mathrm{CO}_{2}$.

U937 cells were seeded at a density of $5 \times 10^{5}$ cells/well into 10-cm culture dish with RPMI-1640 containing 10\% FBS and $100 \mathrm{ng} / \mathrm{ml}$ PMA. After $72 \mathrm{~h}$ of culture, the cells were washed with phosphate-buffered saline (PBS, pH 7.2) and incubated with IL-4 $(20 \mathrm{ng} / \mathrm{ml})$ for the indicated times. Then cells were washed with PBS and incubated with serum-free 1640 for 24 h. After 24-h serum starvation, cells were collected and used as M2-polarized TAMs, and the medium was collected and prepared as M2-polarized TAM-conditioned medium (TAM-CM). The supernatants and cells were collected and stored at $-80^{\circ} \mathrm{C}$ until use.

Morphological characterization and flow cytometry. Morphological characterization of U937 cells and PMA-IL-4-treated U937 cells was acquired by phase-contrast microscopy. Cells were washed with PBS and resuspended in PBS. Cells were then incubated in Clear Back (human Fc receptor blocking reagent) (MBL, Nagoya, Japan) for $20 \mathrm{~min}$ followed by incubation with FITC-mouse anti-human CD206 (BD Biosciences) for $60 \mathrm{~min}$ on ice in the dark. After the final washing step, labeled cells were analyzed by flow cytometry (BD Accuri C6).

Cell viability assay. 5-diphenyltetrazolium bromide (MTT) assay was used to measure cell viability.Briefly, cells were plated in 96-well culture plates at the density of $5-10 \times 10^{3}$ per well in complete medium. After 24-h incubation, cells were treated with BFD $(0-80 \mathrm{mg} / \mathrm{ml})$ in serum-free medium or TAM-CM for $24 \mathrm{~h}$. Then the cells were incubated with $100 \mu 10.5 \mathrm{mg} / \mathrm{ml}$ MTT at $37^{\circ} \mathrm{C}$ for $4 \mathrm{~h}$, and the precipitate was dissolved in $150 \mu \mathrm{l}$ dimethylsulfoxide (DMSO). After shaking for $10 \mathrm{~min}$, the optical density at $570 \mathrm{~nm}$ was measured and the $\mathrm{IC}_{50}$ value was calculated on the non-linear regression fit method by Graphpad Prism 5.0 software (San Diego, CA, USA).

Transwell assay. Cell migration and invasion were performed in 24-well plates using transwell chambers (Corning Inc., Corning, NY, USA) fitted with a polyethylene terephthalate filter membrane with $8-\mu$ m pores. Cells $\left(5 \times 10^{4}\right)$ were seeded in serum-free medium in the upper chamber (normal chamber for migration assay and matrigel-coated chamber for invasion assay). The lower chamber was filled with medium containing 10 or $20 \% \mathrm{FBS}$. After incubating for $24 \mathrm{~h}$ at $37^{\circ} \mathrm{C}$, cells in the upper chamber were carefully removed with a cotton swab, and the cells that had traversed to reverse face of the membrane were cleaned and fixed in methanol, stained with crystal violet. Images were taken with a microscope and cells were counted under 5 randomly chosen fields.

RNA extraction and quantitative real-time PCR. Total RNA was extracted from cells using TRIzol reagent according to the manufacturer's instructions (Invitrogen Life Technologies).
The concentration and quality of the extracted RNA were measured with a NanoDrop 2000 (Thermo Fisher Scientific, Wilmington, DE, USA). The first-strand cDNA was generated using the TransScript first-strand cDNA synthesis supermix (Transgen, Beijing, China) according to the manufacturer's instructions. Primers designed for PCR were synthesized by Sangon Biotech Co., Ltd. (Shanghai, China) and are shown below. The RT-PCR assay was performed using SYBR green qPCR supermix (Applied Biosystems Life Technologies, Foster City, CA, USA) in an ABI PRISM 7500 sequence detection system (Applied Biosystems Life Technologies). The PCR specific primers were 5'-GAC TTT AAG GGT TAC CTG GGT TG-3' (forward) and 5'-TCA CAT GCG CCT TGA TGT CTG-3' (reverse) for IL-10, 5'-GGA CAA GCA GTG ACC ATC AAG-3' (forward) and 5'-CCC AGA ATT ACC AAG TGA GTC CT-3' (reverse) for PD-L1, 5'-GGT GAA GGT CGG TGT GAA CG-3' (forward) and 5'-CTC GCT CCT GGA AGA TGG TG-3' (reverse) for GADPH. The conditions as shown below: $55^{\circ} \mathrm{C}$ for $10 \mathrm{~min}$, followed by 40 cycles of $95^{\circ} \mathrm{C}$ for $30 \mathrm{sec}, 55-59^{\circ} \mathrm{C} 30 \mathrm{sec}$ and $72^{\circ} \mathrm{C}$ for $42 \mathrm{sec}$. The fold changes of each gene were calculated using the $\Delta \Delta \mathrm{Ct}$ (cycle threshold) method, and gene expression levels were normalized by GADPH.

Western blotting. The cells were plated in dishes at a density of $5 \times 10^{5}$ cells $/ \mathrm{ml}$, which were treated with BFD $(0-80 \mathrm{mg} / \mathrm{ml})$ in serum-free medium or TAM-CM for $48 \mathrm{~h}$. After the treatment, the cells were washed in PBS and lysed with RIPA lysis buffer (CWBio, Beijing, China). Total protein of tumor tissues was extracted as above. Protein concentrations were determined using the BCA protein assay kit (Thermo Fisher Scientific, Rockford, IL, USA). The samples corresponding to $20 \mu \mathrm{g}$ of protein were boiled for 8-10 min, resolved on an 8-15\% denatured SDS polyacrylamide gel, and transferred onto a PVDF membrane (Millipore, Bedford, MA, USA). After blocking non-specific binding sites for $1 \mathrm{~h}$ using 5\% skim milk, the membranes were incubated with specific antibodies overnight at $4^{\circ} \mathrm{C}$. The membranes were washed with TBST and incubated with a peroxidase-conjugated secondary antibody for $1 \mathrm{~h}$. Visualization of the protein bands was accomplished using an Immobilon Western Chemiluminescent HRPS substrate (Millipore). ImageJ software was used to calculate the expression of each protein, which was normalized by $\beta$-actin.

Regulation of PD-L1 expression. In order to verify whether it was IL-10 in TAMs that regulated the expression of PD-L1 in NSCLC cells. TAM-CM with neutralizing mAbs against IL-10 (eBioscience) or recombinant human (rh) cytokines IL-10 was used instead of TAM-CM in the culture system, and PD-L1 expression was detected by western blotting as mentioned above. The level of IL-10 in culture supernatants was detected by ELISA, and concrete implementation method was in accordance with manufacturers specifications.

Determination of antitumor effect in nude mice. Female BALB/c nude mice (6-8-week-old) were obtained from Peking University Health Science Center (Beijing, China). The animals were kept under a specific pathogen-free (SPF) condition with a 12-h light/dark cycle and freely accessed autoclaved standard food and water. The animal experiment protocol was 
A
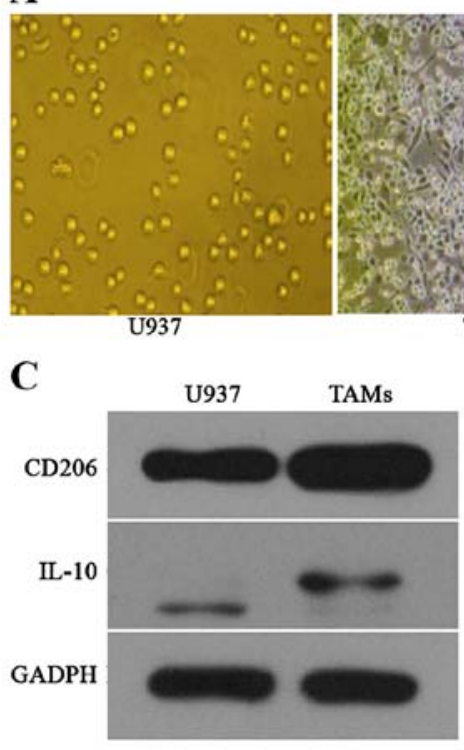

D
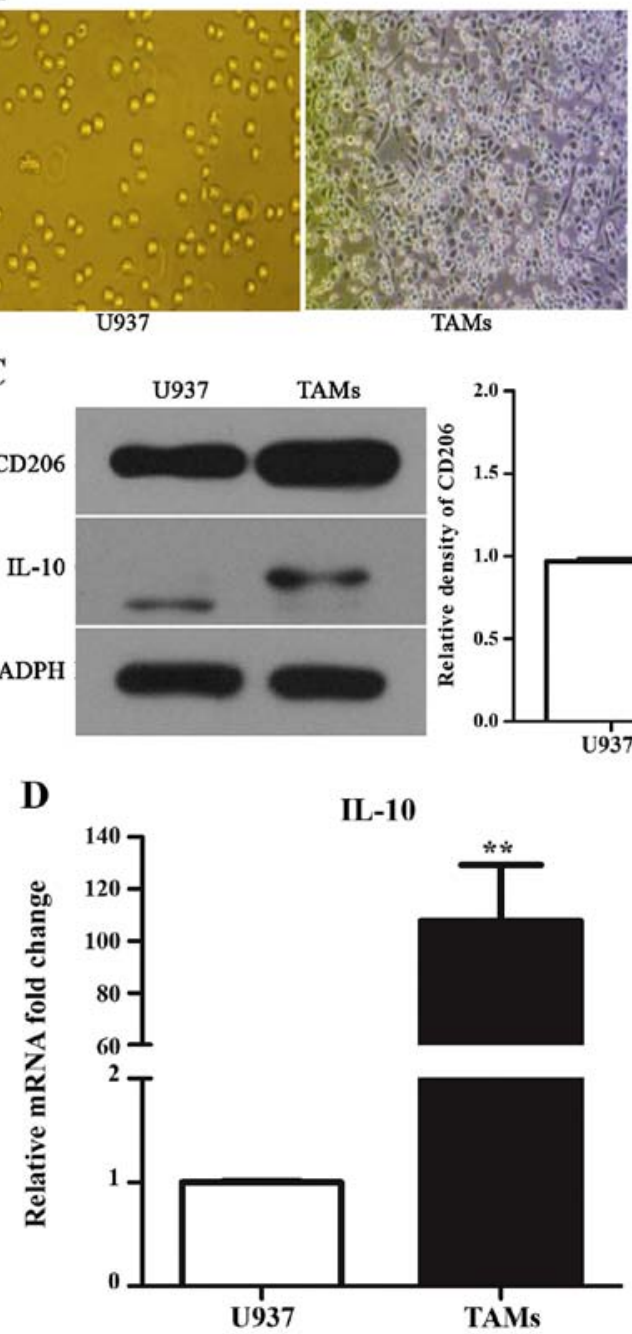

B
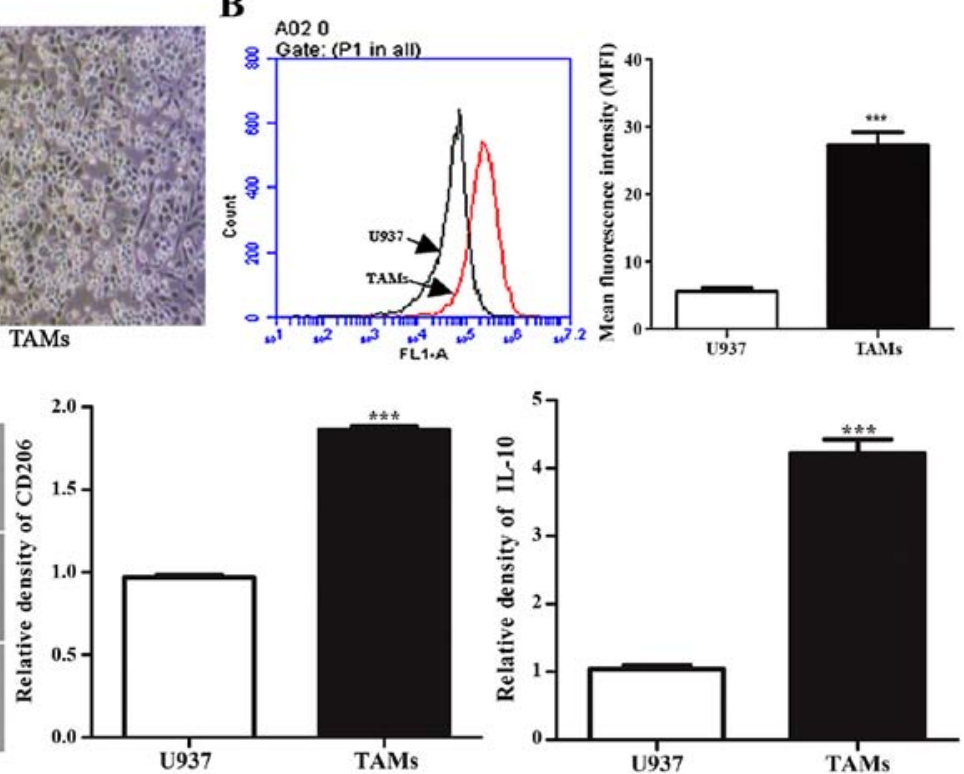

E

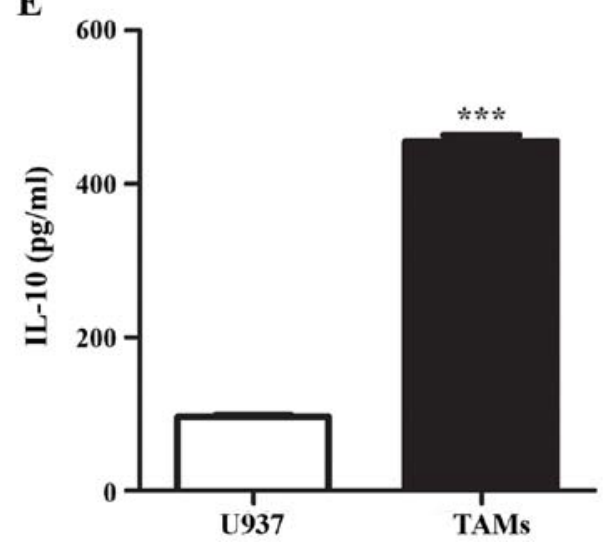

Figure 1. PMA and IL-4 promotes the differentiation of human U937 monocytic cells into tumor associated macrophages. (A) Representative images of U937 cells and TAMs cells. (B) The expression of TAMs markers CD206 was analyzed by flow cytometry. (C) The expression of CD206 and IL-10 was analyzed by western blotting. (D) The relative mRNA fold change of IL-10 was analyzed by RT-PCR. (E) The expression of IL-10 in culture medium was analyzed by ELISA. ${ }^{* *} \mathrm{p}<0.01,{ }^{* * * *} \mathrm{p}<0.001$ vs U937 cells.

approved by Peking University Animals Research Committee and conducted in accordance with European community guide lines. Human NSCLC cell lines A549 $\left(3 \times 10^{6}\right)$ or H1975 $\left(3 \times 10^{6}\right)$ cells were suspended in $0.25 \mathrm{ml}$ of PBS mixed 1:1 with Matrigel (BD Biosciences) and subcutaneously inoculated into the right flank of nude mice.

The daily dosage for nude mice was obtained based on the daily dosage for humans at $0.58 \mathrm{~g} / \mathrm{kg}$ (equivalent to a crude drug dose of $1.23 \mathrm{~g} / \mathrm{kg}$ ) in clinical. After calculation using the human-mouse transfer formula, the dosage of BFD for nude mice was determined to be 30 and $60 \mathrm{~g} / \mathrm{kg}$, which were 2 and 4 times the anticipated clinical dosage, respectively. The human-mouse transfer formula: Animal dose = Human dose $\mathrm{x}\left(\mathrm{HK}_{\mathrm{m}} / \mathrm{AK}_{\mathrm{m}}\right)$, where $\mathrm{HK}_{\mathrm{m}}$ and $\mathrm{AK}_{\mathrm{m}}$ represent the $\mathrm{K}_{\mathrm{m}}$ factor of human (Human $\mathrm{K}_{\mathrm{m}}: 37$ ) and mouse (Mouse $\mathrm{K}_{\mathrm{m}}: 3$ ) (33).

Tumor growth was measured with tumor volume by the following formula: tumor volume $\left(\mathrm{mm}^{3}\right)=1 / 2 \mathrm{x}$ length $\mathrm{x}$ width ${ }^{2}$. When the tumors reached a size range of $50-100 \mathrm{~mm}^{3}$, the mice were randomly divided into 3 groups $(n=8-10)$ : control, BFD $(30 \mathrm{~g} / \mathrm{kg})$ and BFD $(60 \mathrm{~g} / \mathrm{kg})$. All the compounds were administered orally twice a day for consecutive 21 days, and then the tumor volume and body weight of the mice were measured every 3 days during the administration period.

At the end of study, blood was gained from the eyeballs of mice, and their tumors were removed and weighed after the animals were sacrificed. Tumor tissues were fixed in formalin for immunohistochemistry analysis or stored at $-80^{\circ} \mathrm{C}$ for protein election.

Statistical analysis. The data were presented as the means $\pm \mathrm{SE}$ of at least three separate experiments. All comparisons were analyzed with Student's two-tailed t-test, with $\mathrm{p}<0.05$ considered statistically significant.

\section{Results}

Successful induction of M2-polarized TAMs. As shown in Fig. 1A, compared with native cells, PMA-IL-4 treated U937 cells attached to the culture dish and developed elongated macrophage-like projections. Western blotting and flow cytometry results (Fig. $1 \mathrm{~B}$ and $\mathrm{C}$ ) showed that the mannose 

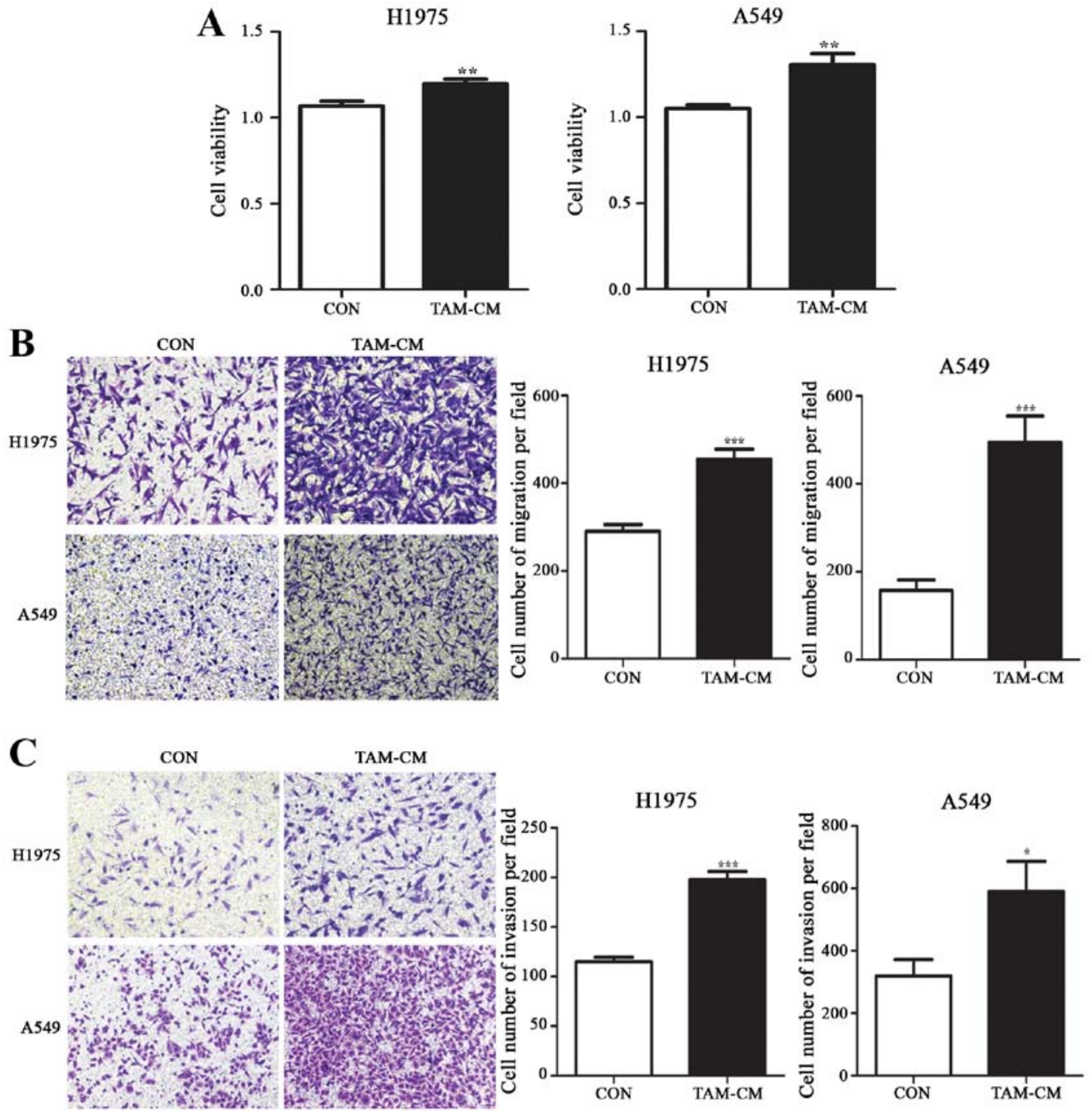

Figure 2. Coculture with TAMs increases the proliferation, migration and invasion of NSCLC cells. (A) Cell survival rates were increased by $11.9 \%$ in H1975 and 24.3\% in A549. (B) TAMs promoted more H1975 and A549 cell migration to the lower chamber. (C) TAMs promoted more H1975 and A549 cell invasion to the lower chamber. CON, routine medium; TAM-CM, tumor associated macrophage conditioned medium. ${ }^{*} \mathrm{p}<0.05,{ }^{* *} \mathrm{p}<0.01,{ }^{* * * *} \mathrm{p}<0.001 \mathrm{vs} \mathrm{CON}$.

receptor CD206 was significantly higher than native cells $(\mathrm{p}<0.05)$. The mRNA and protein expression levels of IL-10 were obviously increased in PMA-IL-4 treated U937 cells $(\mathrm{p}<0.05)$ (Fig. 1C-E). The above results suggested that IL-4 (20 ng/ml) and PMA (100 ng/ml) successfully induced the alteration of classical macrophages to M2-polarized TAMs.

Coculture with M2-polarized TAMs increased the proliferation, migration and invasion of NSCLC cells. The coculture system between TAMs and NSCLC cells was established by culturing cancer cells in M2-polarized TAM-conditioned medium (TAM-CM). We next examined the effects of TAMs on NSCLC cell proliferation, migration and invasion. Compared with routine medium, coculture with TAMs significantly increased the cell viability in both $\mathrm{H} 1975$ and A549 cells. Cell survival rates were increased by $11.9 \%$ in $\mathrm{H} 1975$ and $24.3 \%$ in A549, p<0.01 (Fig. 2A).

TAMs significantly promoted more H1975 and A549 cell migration to the lower chamber. Compared with the control group, the number of migrated cells in TAM-CM was
454.5 \pm 23.49 and 494.1 \pm 60.18 in H1975 and A549 cells, respectively; whereas the corresponding cell number was $290.9 \pm 15.2$ and 157.4 \pm 24.22 , in the control group (p<0.001) (Fig. 2B).

The invasive ability of cancer cells in TAM-CM underwent similar alterations as the migratory ability. The number of invaded cells in TAM-CM was 197.6 \pm 8.617 and 590.3 \pm 96.52 in H1975 and A549 cells, compared to the cells in routine medium, with the invaded cell number of $115.0 \pm 4.402$ and 319.6 \pm 52.36 , respectively ( $\mathrm{p}<0.05$ ) (Fig. 2C).

Dose-dependent suppression of NSCLC cell proliferation, migration and invasion by BFD in TAM conditioned medium. NSCLC cell proliferation was reduced by BFD in a dose-dependent manner, especially in H1975 cells with an $\mathrm{IC}_{50}$ of $22.84 \mathrm{mg} / \mathrm{ml}$ in routine medium and $49.36 \mathrm{mg} / \mathrm{ml}$ in TAM-CM. The inhibition of A549 cells was relatively weak, the $\mathrm{IC}_{50}$ was $75.80 \mathrm{mg} / \mathrm{ml}$ in routine medium and $73.62 \mathrm{mg} / \mathrm{ml}$ in TAM-CM (Fig. 3A).

The number of migrated cells was reduced gradually BFD dose-dependently, and there was a significant difference in 

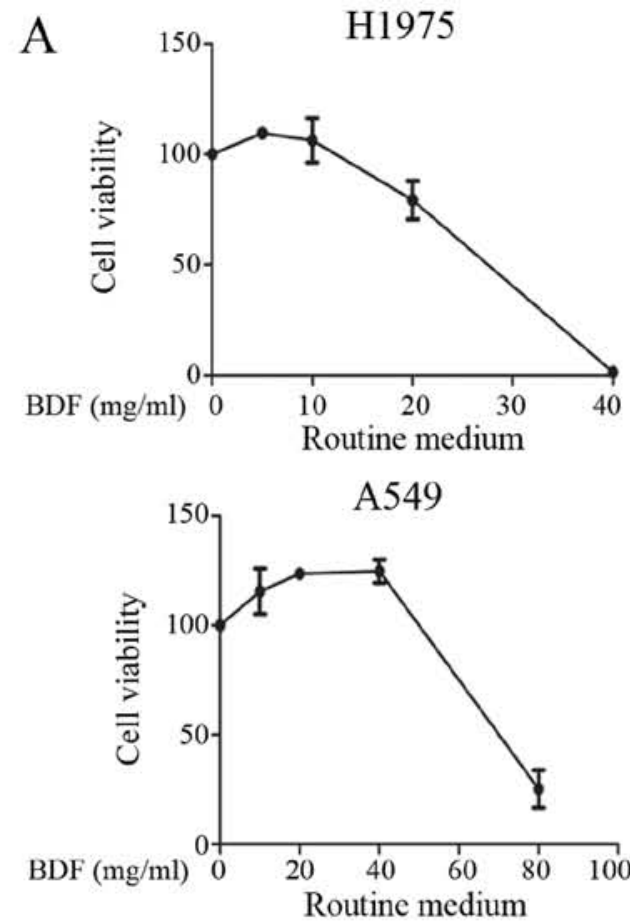

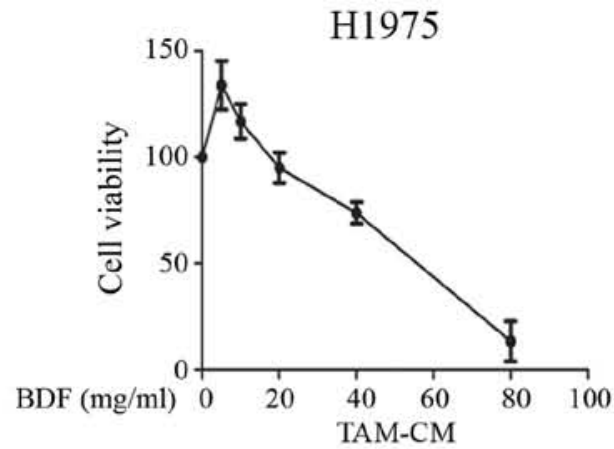

A549

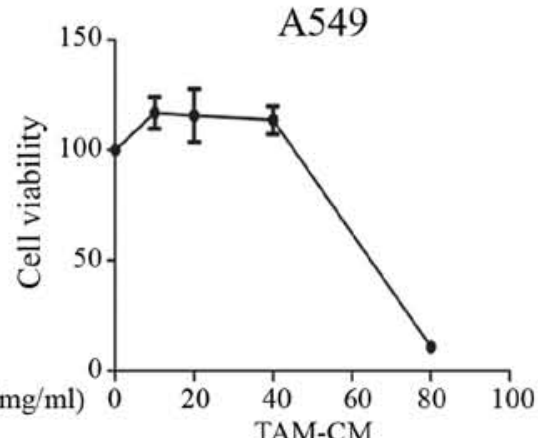

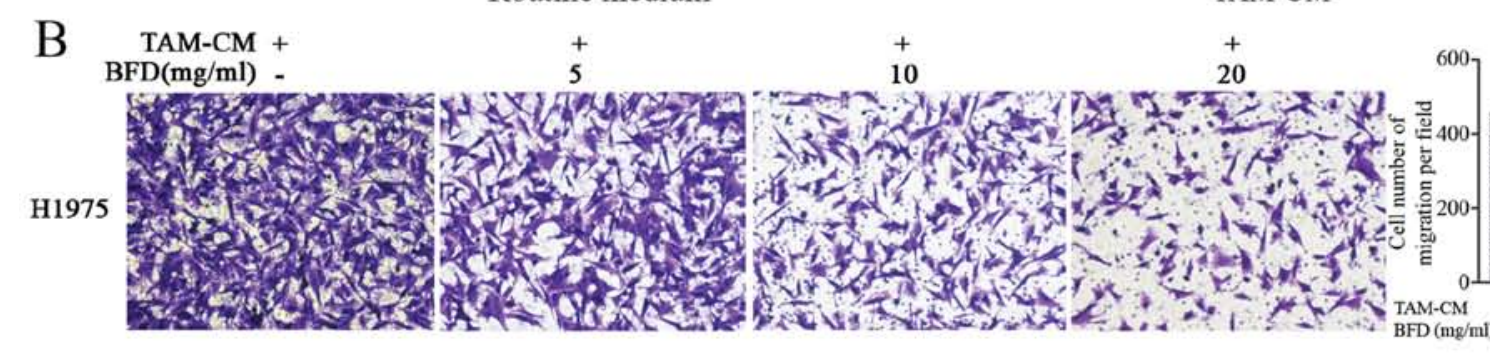

H1975

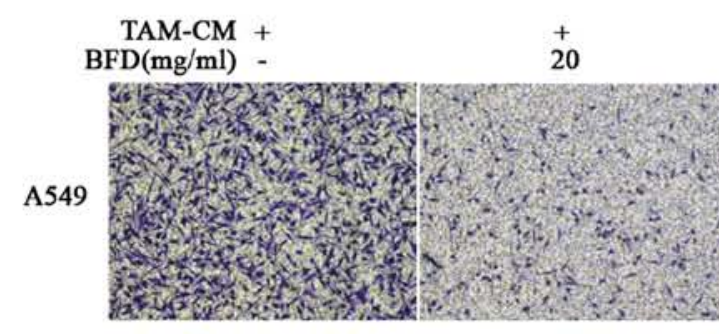

$+\underset{40}{+}$

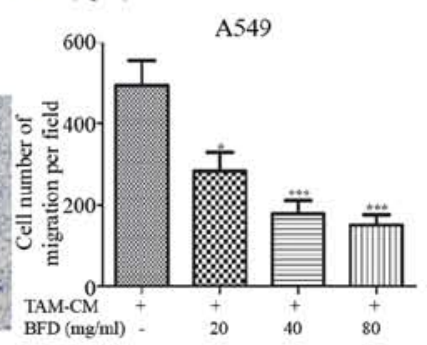

C $\begin{array}{r}\text { TAM-CM + } \\ \text { BFD(mg/ml) - }\end{array}$

$+$

$+$

$+$

H1975
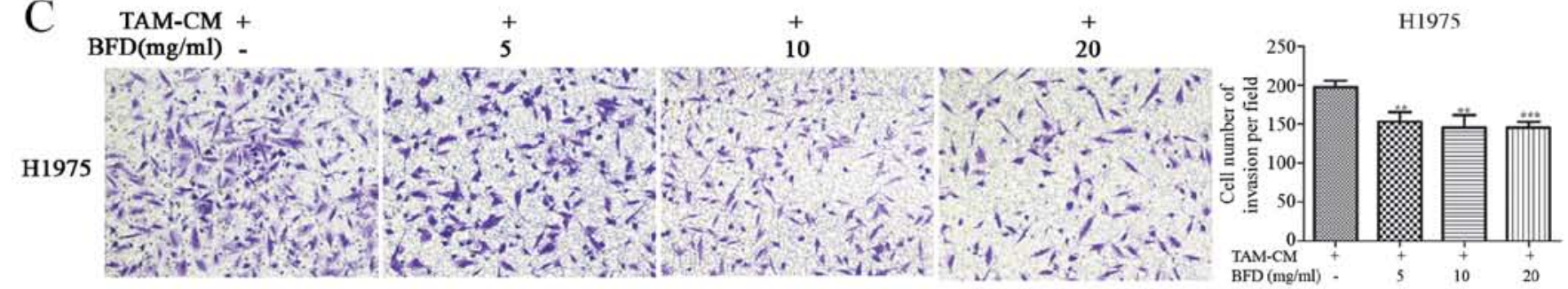

$\mathrm{TAM}-\mathrm{CM}+$

$\stackrel{+}{20}$

$\stackrel{+}{40}$

$\stackrel{+}{80}$

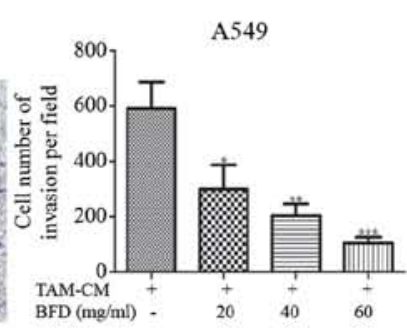

Figure 3. Dose-dependent suppression of NSCLC cell proliferation, migration and invasion by BFD. (A) Cell proliferation was reduced by BFD, H1975: $\mathrm{IC}_{50}, 22.84 \mathrm{mg} / \mathrm{ml}$ (routine medium), IC $\mathrm{I}_{50}, 49.36 \mathrm{mg} / \mathrm{ml}$ (TAM-CM); A549: IC ${ }_{50}, 75.80 \mathrm{mg} / \mathrm{ml}$ (routine 1640 medium), $\mathrm{IC}_{50}, 73.62 \mathrm{mg} / \mathrm{ml}$ (TAM-CM). (B) The numbers of migrated cell permeating septum were reduced by BFD. (C) The invasive ability of cells was decreased by BFD, "p $<0.05$, "p $<<0.01$, ${ }^{* * * *} \mathrm{p}<0.001$ vs TAM-CM. 

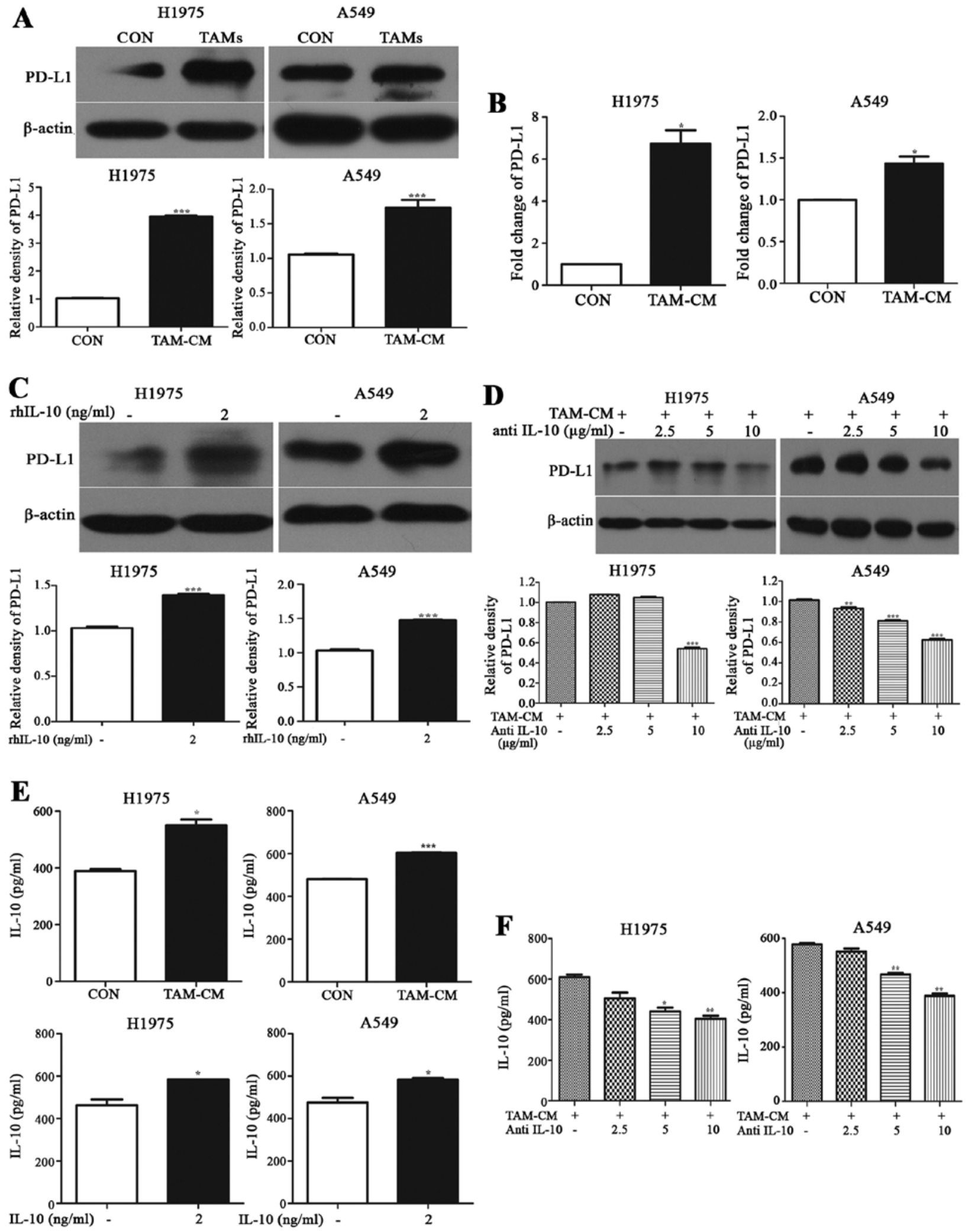

Figure 4. IL-10 secreted from TAMs promotes PD-L1 expression on NSCLC cells. (A and B) The mRNA and protein expressions of PD-L1 in H1975 and A549 cells was increased by TAM-CM. (C) rhIL-10 promoted PD-L1 expression on cancer cells like TAM-CM. (D) Anti-IL-10 mAb gradually weakened the upregulation of PD-L1 on A549 and H1975 cells induced by TAM-CM. (E) The level of IL-10 in TAM-CM or rhIL-10 culture system was higher than the control group. (F) The level of IL-10 in TAM-CM with anti-IL-10 and cancer cell coculture system was greatly lower than the TAM-CM group, ${ }^{\text {p }}<0.05$, ${ }^{* *} \mathrm{p}<0.01,{ }^{* * *} \mathrm{p}<0.001$.

comparison to TAMs. The number of migrated H1975 cells was $368.0 \pm 30.65,326.0 \pm 11.45$ and $139.5 \pm 34.23$ with BFD at dose of 5,10 and $20 \mathrm{mg} / \mathrm{ml}$, respectively, $\mathrm{p}<0.05$. While for
A549 cells, the number was $283.0 \pm 45.82,178.1 \pm 33.06$ and $150.7 \pm 25.48$ with BFD at dose of 20,40 and $80 \mathrm{mg} / \mathrm{ml}$, respectively, p $<0.05$ (Fig. 3B). 

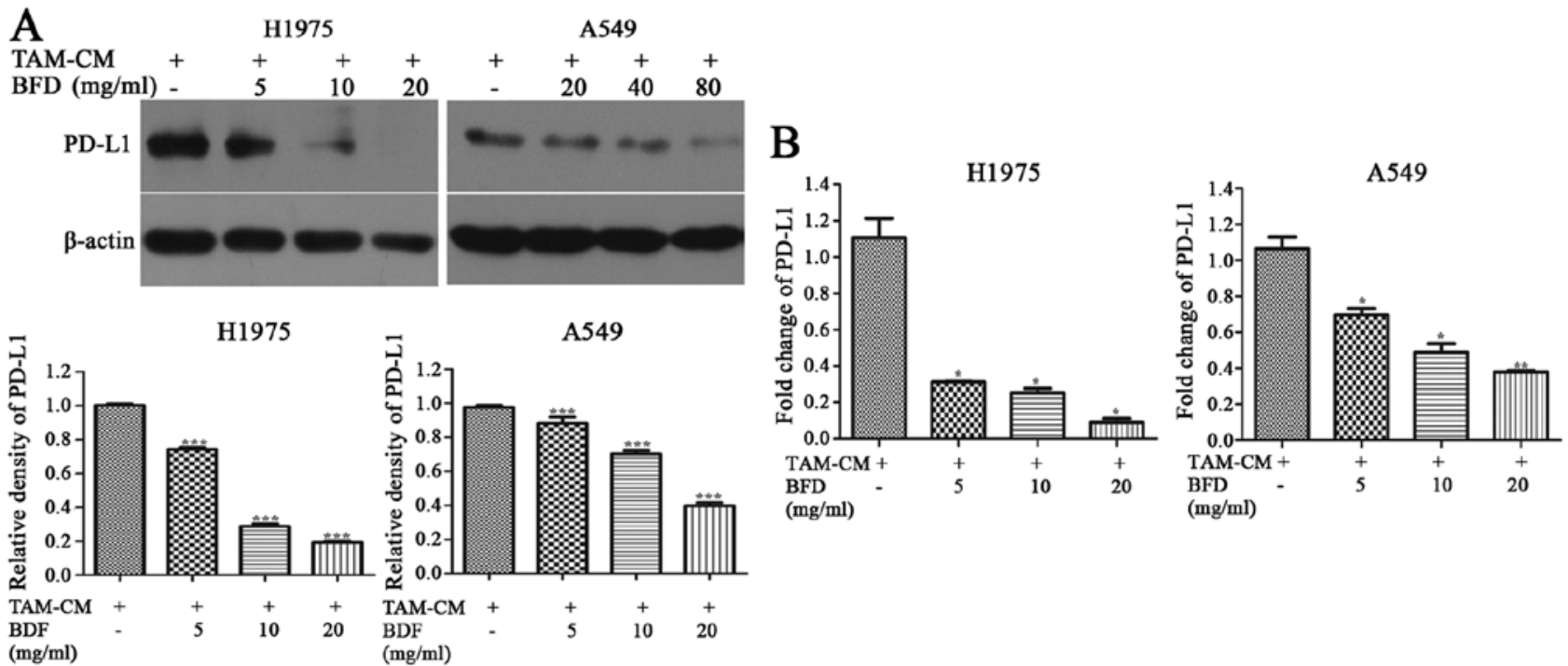

C
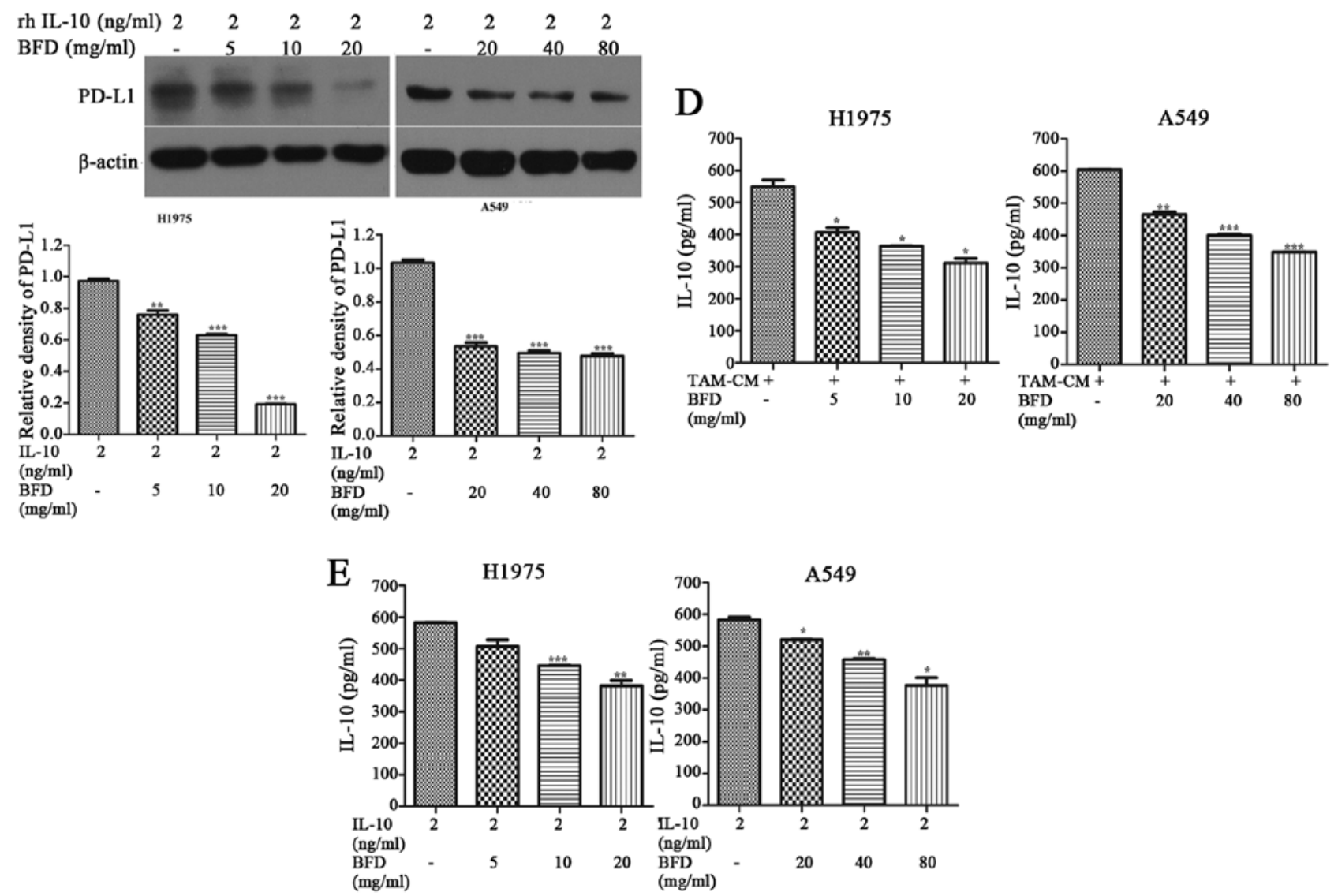

Figure 5. BFD reduces the expression of IL-10 and PD-L1 in vitro. (A) The protein expression of PD-L1 on A549 and H1975 cells cocultured with TAMs was gradually inhibited BFD dose-dependently. (B) PD-L1 mRNA expression in H1975 and A549 cells was decreased BFD dose-dependently. (C) The expression of PD-L1 in NSCLC cells induced by rhIL-10 was also inhibited BFD dose-dependently. (D) The level of IL-10 in TAMs and cancer cells coculture system was decreased BFD dose-dependently. (E) BFD decreased the level of IL-10 in NSCLC culture system induced rhIL-10 dose-dependently, ${ }^{*} \mathrm{p}<0.05,{ }^{* *} \mathrm{p}<0.01,{ }^{* * *} \mathrm{p}<0.001$.

The invasive ability of cancer cells was also decreased BFD dose-dependently. Compared with the TAM-CM, the number of invaded cells for H1975 cells was $153.1 \pm 12.44$, $145.8 \pm 15.99$ and $145.7 \pm 7.276$ with BFD at dose of 5,10 and $20 \mathrm{mg} / \mathrm{ml}$, respectively, $\mathrm{p}<0.01$. For A549 cells, the number was $300.0 \pm 87.8,203.8 \pm 42.42$ and $105.1 \pm 21.71$ with BFD at dose of 20,40 and $80 \mathrm{mg} / \mathrm{ml}$, respectively, $\mathrm{p}<0.05$ (Fig. 3C).
IL-10 secreted from TAMs promotes PD-L1 expression in NSCLC cells. Real-time PCR and western blotting showed that the mRNA and protein expression of PD-L1 were higher in cancer cells cocultured with M2-polarized TAMs than those in monoculture (Fig. 4A and B). Compared with the control group, the protein expression of PD-L1 in cancer cells cocultured with TAMs was increased $\sim 3$-fold in H1975 and 0.7-fold 

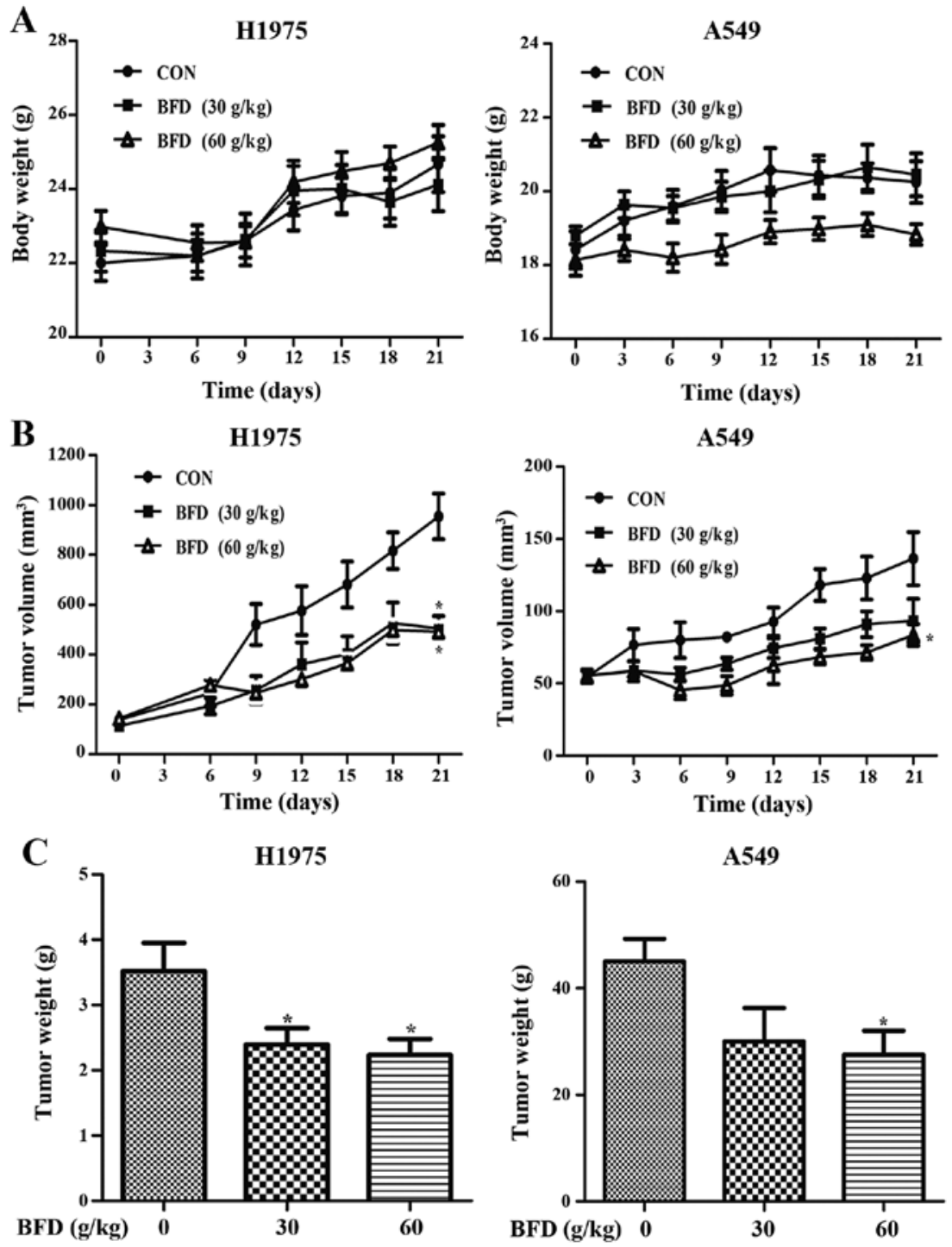

Figure 6. BFD suppresses A549 and H1975 tumor growth in xenograft mice. (A) The body weight was not decreased by BFD compared with the control group (p>0.05). (B) In H1975 xenograft mice, tumor volume and tumor weight was suppressed by BFD dose-dependently ( $<<0.05)$. (C) In A549 xenograft mice, the tumor volume and tumor weight was decreased by BFD dose-dependently $(\mathrm{p}<0.05),{ }^{*} \mathrm{p}<0.05,{ }^{* *} \mathrm{p}<0.01,{ }^{* * *} \mathrm{p}<0.001$.

in A549, respectively $(\mathrm{p}<0.001)$. mRNA level was increased 6.7-fold in H1975 and 1.432-fold in A549, in comparison with those of the control group $(\mathrm{p}<0.05)$.

We tested the expression of PD-L1 in cancer cells in rhIL-10 or TAM-CM with neutralizing mAbs against IL-10 instead of TAM-CM. As shown in Fig. 4C, compared with the control group, rhIL-10 promoted PD-L1 expression on A549 and H1975 cells like TAMs, and the difference was statistically significant $(\mathrm{p}<0.01)$. While TAM-CM with anti-IL-10 $\mathrm{mAb}$ gradually weakened the upregulation of PD-L1 on A549 and H1975 cells ( $<<0.05$, Fig. 4D).

The level of IL-10 in TAM coculture system was higher than cancer cells in monoculture. The level of IL-10 was increased by $41.27 \%(\mathrm{p}<0.05)$ in $\mathrm{H} 1975$ and $25.68 \%(\mathrm{p}<0.001)$ in A549 coculture system, respectively. It was increased by $25.87 \%(\mathrm{p}<0.05)$ in $\mathrm{H} 1975$ and $22.48 \%(\mathrm{p}<0.05)$ in A549, respectively (Fig. 4E).

The level of IL-10 in TAM-CM with anti-IL-10 coculture system was greatly lower than the TAM-CM group. The level of IL-10 in H1975 treated with anti-IL-10 at a dose of $2.5,5$ and $10 \mu \mathrm{g} / \mathrm{ml}$ showed a $17.12(\mathrm{p}>0.05), 27.74(\mathrm{p}<0.05)$ and $33.62 \%(\mathrm{p}<0.01)$ decrease, respectively. Similarly, IL-10 level in A549 decreased by $4.60(\mathrm{p}>0.05), 19.10(\mathrm{p}<0.01)$ and $32.85 \%(\mathrm{p}<0.01)$ using $2.5,5$ and $10 \mu \mathrm{g} / \mathrm{ml}$ anti-IL-10 treatment (Fig. 4F). It was established that IL-10 secreted by TAMs induced PD-L1 expression in NSCLC cells.

$B F D$ reduces the expression of $I L-10$ and $P D-L 1$ in vitro. After cancer cells were treated with different doses of BFD, the protein and mRNA expression of PD-L1 in NSCLC cells cocultured with TAMs was gradually inhibited in comparison with the TAM-CM group. The protein expression of PD-L1 in H1975 treated with BFD at a dose of 5, 10 and $20 \mathrm{mg} / \mathrm{ml}$ showed a $25.92(\mathrm{p}<0.001), 71.32(\mathrm{p}<0.001)$ and $80.74 \%(\mathrm{p}<0.001)$ decrease, respectively. Similarly, PD-L1 protein in A549 decreased by $28.64(\mathrm{p}<0.01), 36.49$ $(p<0.01)$ and $70.57 \%(p<0.001)$ using 20,40 and $80 \mathrm{mg} / \mathrm{ml}$ BFD treatment (Fig. 5A). PD-L1 mRNA expression levels 
in H1975 treated with BFD at a dose of 5, 10 and $20 \mathrm{mg} / \mathrm{ml}$ showed a $71.84(\mathrm{p}<0.05), 77.27(\mathrm{p}<0.05)$ and $91.97 \%(\mathrm{p}<0.05)$ decrease, respectively. Similarly, PD-L1 mRNA expression in A549 was decreased by $34.71(\mathrm{p}<0.05), 54.30(\mathrm{p}<0.05)$ and $64.47 \%(\mathrm{p}<0.01)$ using 20, 40, and $80 \mathrm{mg} / \mathrm{ml}$ BFD treatment (Fig. 5B).

PD-L1 in NSCLC cells induced by rhIL-10 was also inhibited BFD dose-dependently. Compared with the rhIL-10 group, PD-L1 in H1975 treated with BFD at a dose of 5, 10 and $20 \mathrm{mg} / \mathrm{ml}$ showed a $21.99(\mathrm{p}<0.001), 35.36(\mathrm{p}<0.001)$ and $80.28 \%(\mathrm{p}<0.001)$ decrease, respectively. Similarly, PD-L1 in A549 decreased by $48.26(\mathrm{p}<0.001), 53.45(\mathrm{p}<0.001)$ and $55.16 \%(\mathrm{p}<0.001)$ using 20, 40 and $80 \mathrm{mg} / \mathrm{ml}$ BFD treatment (Fig. 5C).

IL-10 in TAM coculture system was decreased by BFD dose-dependently. Compared with the TAM-CM group, IL-10 in H1975 treated with BFD at a dose of 5, 10 and $20 \mathrm{mg} / \mathrm{ml}$ showed a $26.01(\mathrm{p}<0.05), 33.89(\mathrm{p}<0.05)$ and $43.42 \%(\mathrm{p}<0.05)$ decrease, respectively. Similarly, IL-10 in A549 decreased by $22.98(\mathrm{p}<0.01), 33.76(\mathrm{p}<0.001)$ and $42.21 \%(\mathrm{p}<0.001)$ using 20, 40 and $80 \mathrm{mg} / \mathrm{ml} \mathrm{BFD} \mathrm{(Fig.} \mathrm{5D).}$

BFD decreased IL-10 in NSCLC culture system induced rhIL-10 dose-dependently. Compared with the rhIL-10 group, IL-10 in H1975 treated with BFD at a dose of 5, 10 and $20 \mathrm{mg} /$ $\mathrm{ml}$ showed a $12.93(\mathrm{p}>0.05), 23.46(\mathrm{p}<0.001)$ and $34.51 \%$ $(\mathrm{p}<0.01)$ decrease, respectively. IL-10 in A549 decreased by $11.2(\mathrm{p}<0.05), 21.44(\mathrm{p}<0.01)$ and $35.38 \%(\mathrm{p}<0.05)$ using 20,40 and $80 \mathrm{mg} / \mathrm{ml} \mathrm{BFD} \mathrm{(Fig.} \mathrm{5E).}$

BFD suppresses A549 and H1975 tumor growth in xenograft mice. We evaluated the anticancer effect of BFD on female nude mice bearing A549 or H1975 tumors. Comparing BFD groups with the control group, there was no significant intergroup difference in body weight during the therapy ( $>0.05$ ) (Fig. 6A). In H1975 xenograft mice, BFD (30 g/kg) group decreased tumor volume and tumor weight to some extent, there was a statistical difference in comparison to the control group $(\mathrm{p}<0.05)$; BFD $(60 \mathrm{~g} / \mathrm{kg})$ group decreased tumor volume and tumor weight to a great extent, and the difference was statistically significant $(\mathrm{p}<0.05)$ (Fig. 6B). In A549 xenograft mice, tumor volume and tumor weight slightly decreased by $30 \mathrm{~g} / \mathrm{kg}$ BFD, there was no statistical difference ( $>0.05)$. While tumor volume and tumor weight greatly decreased with $60 \mathrm{~g} / \mathrm{kg}$ BFD compared with the control group $(\mathrm{p}<0.05)$ (Fig. 6C).

$B F D$ reduces $P D-L 1, I L-10$ and $C D 206$ protein expression in vivo. BFD resulted in a downregulation of PD-L1, IL-10 and CD206 in A549 and H1975 tumor tissue dose-dependently. As shown in Fig. 7A, compared with the control group, BFD 30 and $60 \mathrm{~g} / \mathrm{kg}$ resulted in a downregulation of PD-L1 in H1975 tumor tissue by $25.59(\mathrm{p}<0.001)$ and $38.39 \%(\mathrm{p}<0.001)$, respectively. While for A549 tumor tissue, PD-L1 was decreased by $17.24(\mathrm{p}<0.01)$ in BFD 30 and $29.79 \%(\mathrm{p}<0.001)$ in BFD $60 \mathrm{~g} / \mathrm{kg}$. IL-10 in H1975 tumor tissue was decreased by $51.66(\mathrm{p}<0.001)$ in BFD $30 \mathrm{~g} / \mathrm{kg}$ and $62.44 \%(\mathrm{p}<0.001)$ in BFD $60 \mathrm{~g} / \mathrm{kg}$. While for A549 tumor tissue, BFD 30 and $60 \mathrm{~g} / \mathrm{kg}$ also resulted in a significant decrease in IL-10 by $28.87(\mathrm{p}<0.01)$ and $39.50 \%(\mathrm{p}<0.01)$, respectively. BFD 30 and $60 \mathrm{~g} / \mathrm{kg}$ resulted in a downregulation of CD206 in H1975 tumor tissue by $22.25(\mathrm{p}<0.001)$ and $47.21 \%(\mathrm{p}<0.001)$, respectively. While for A549, CD206 was decreased by $43.7 \%$ ( $<<0.001)$ in BFD $30 \mathrm{~g} / \mathrm{kg}$ and $60.82 \%(\mathrm{p}<0.001)$ in BFD $60 \mathrm{~g} / \mathrm{kg}$.

The serum level of IL-10 was significantly lower BFD dose-dependently, compared with the control group $(\mathrm{p}<0.001)$ (Fig. 7B). Using IHC staining, PD-L1 and IL-10 were analyzed in all tumor specimens. PD-L1-positive cells were evenly scattered throughout the specimens, it was located primarily in the cytoplasm and membrane of tumor cells. IL-10 was also generally expressed in the cytoplasm of tumor cells. The above was consistent with the study of Geng et al (34). Representative IHC staining is shown in Fig. 7C.

\section{Discussion}

IL-10 and PD-L1 are two major immunosuppressor proteins associated with tumorigenesis and tumor progression. Tumor associated macrophages represent key regulators of the complex interplay between the immune system and cancer (35). As a classic compound of TCM, BFD is widely used to alleviate lung cancer related symptoms by improving lung functions and enhancing the body immunity. In our study, conditioned medium from TAMs promoted the expression of PD-L1 in NSCLC cells by secreting IL-10. Furthermore, IL-10 and PD-L1 was decreased by BFD in vitro and in vivo.

M2-polarized TAMs were established in vitro. Taniguchi et al (7) used PMA and IL-4 to treat U937 cells and obtained M2-polarized TAMs. We treated U937 cells as described above. M2-polarized TAMs were successfully induced and confirmed (Fig. 1). Tumor associated macrophage conditioned medium (TAM-CM) was collected and extracted, as described by Liu et al and Chen et al (11,36).

In the present study, TAMs significantly promoted the proliferation, migration and invasion of NSCLC cells, H1975 and A549, as expected (Fig. 2). The results suggested that TAMs provided a suitable microenvironment for tumor progression. Some cytokines may exist in the microenvironment of TAMs probably to promote tumor growth and metastasis. Previous studies also revealed that M2-polarized macrophages induced tumor proliferation, migration and invasion in hepatocellular carcinoma, human basal carcinoma cells, pancreatic cancer and prostate cancer cells $(9,10,17)$. When NSCLC cells were treated with different doses of BFD, the abilities of cell proliferation, migration and invasion induced by TAMs were gradually decreased, and there was a significant difference in comparison to the TAM group (Fig. 3). Thus, we presumed BFD probably inhibited some target cytokine or protein secreted by TAMs, causing change of the tumor microenvironment and interruption of the interaction between TAMs and cancer cells. The next key work is to find target cytokines or protein associated with TAMs and BFD.

Immunosuppressive cytokines (e.g., IL-10 and TGF- $\beta$ ) or proteases secreted by TAMs probably play an important role in tumor progression. IL-10 may tune inflammatory responses and adaptive Th2 immunity, which strongly inhibits Th1 cytokines $(\mathrm{IFN}-\gamma)$ to exert antitumor effect, and the tumor progression is accelerated (37-39). As another important immunosuppressive protein, PD-L1 is a co-inhibitory molecule expressed generally on antigen-presenting cells and tumor cells (40). By binding 
A
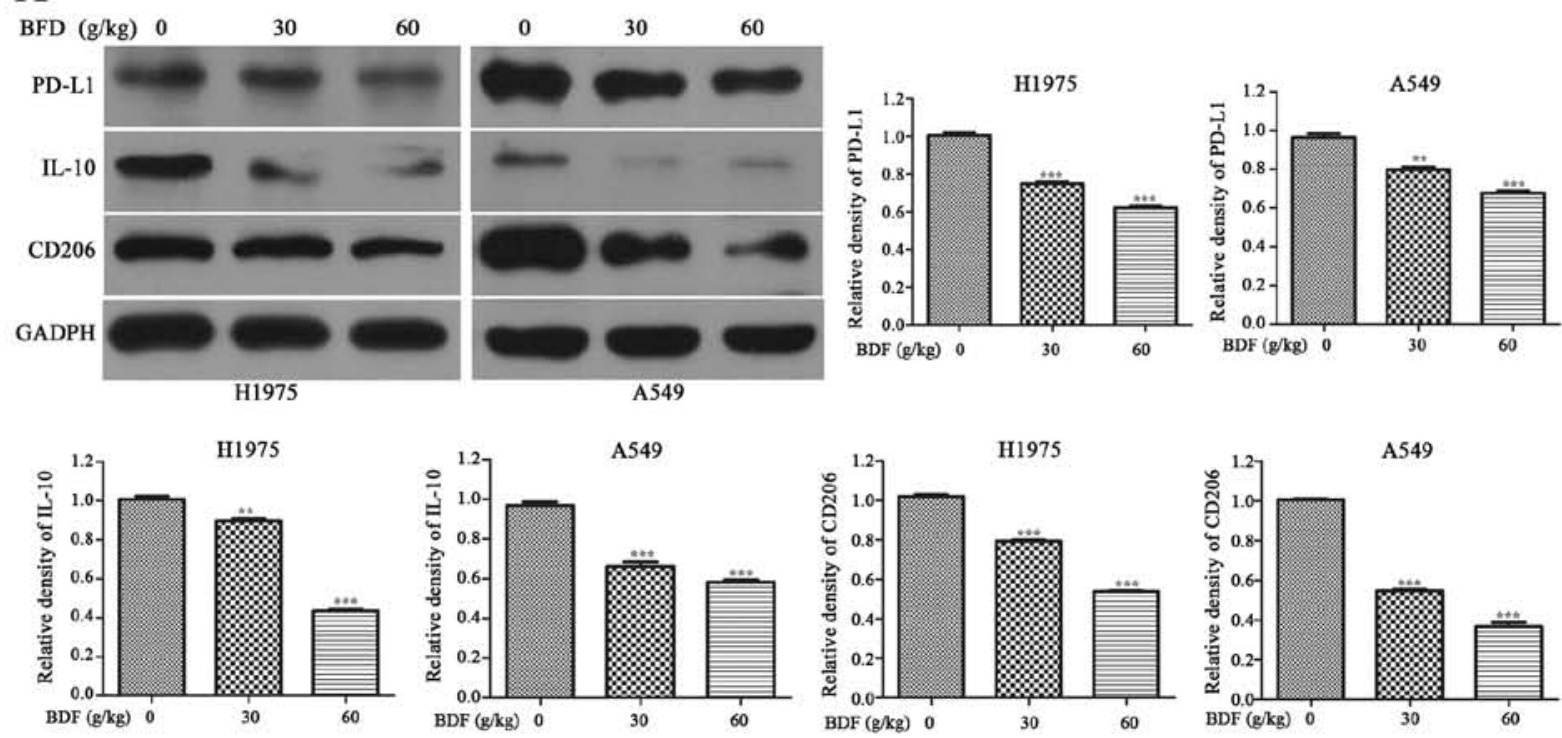

C
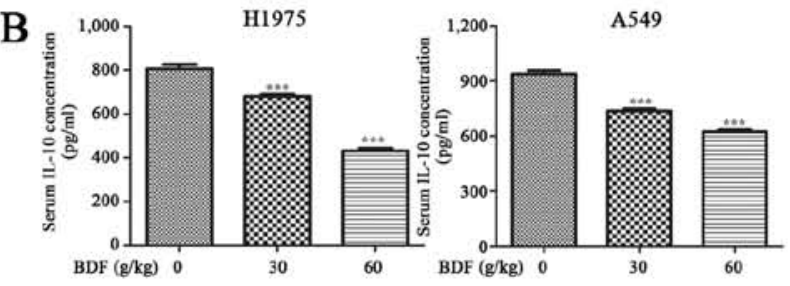

PD-L1
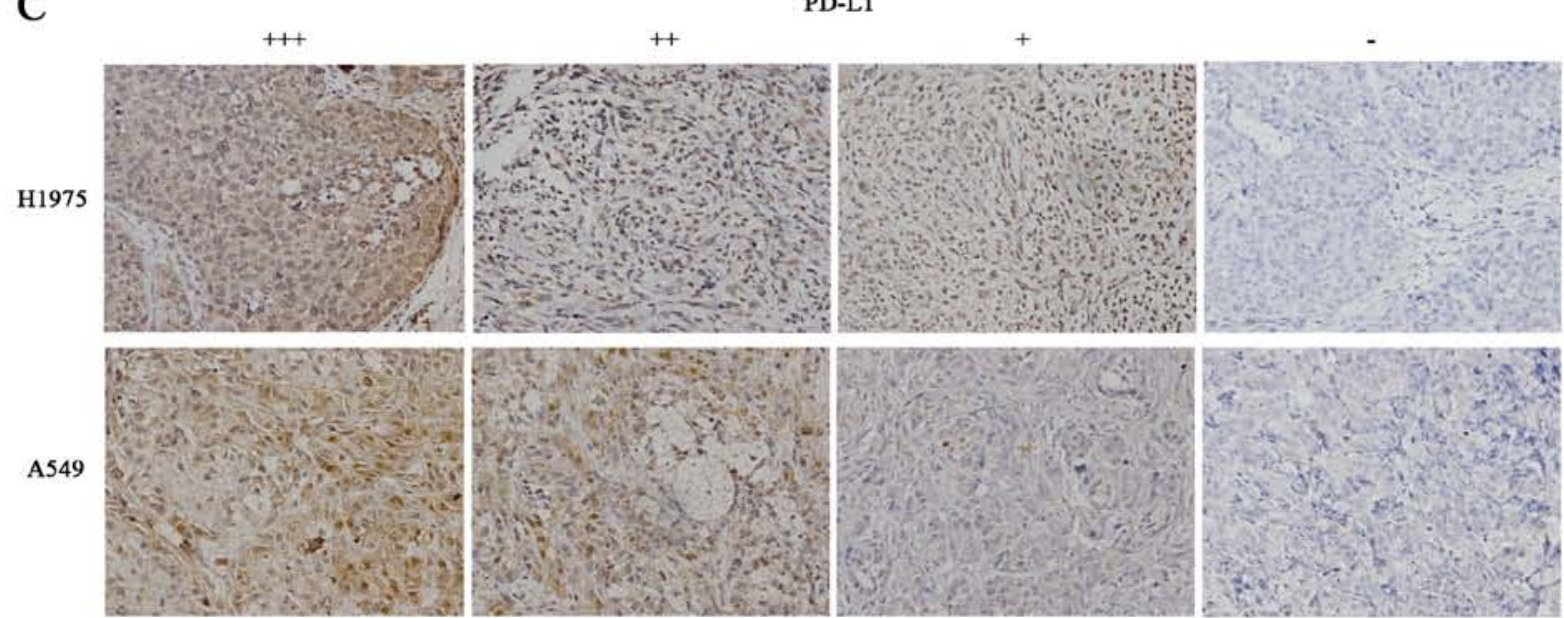

IL-10
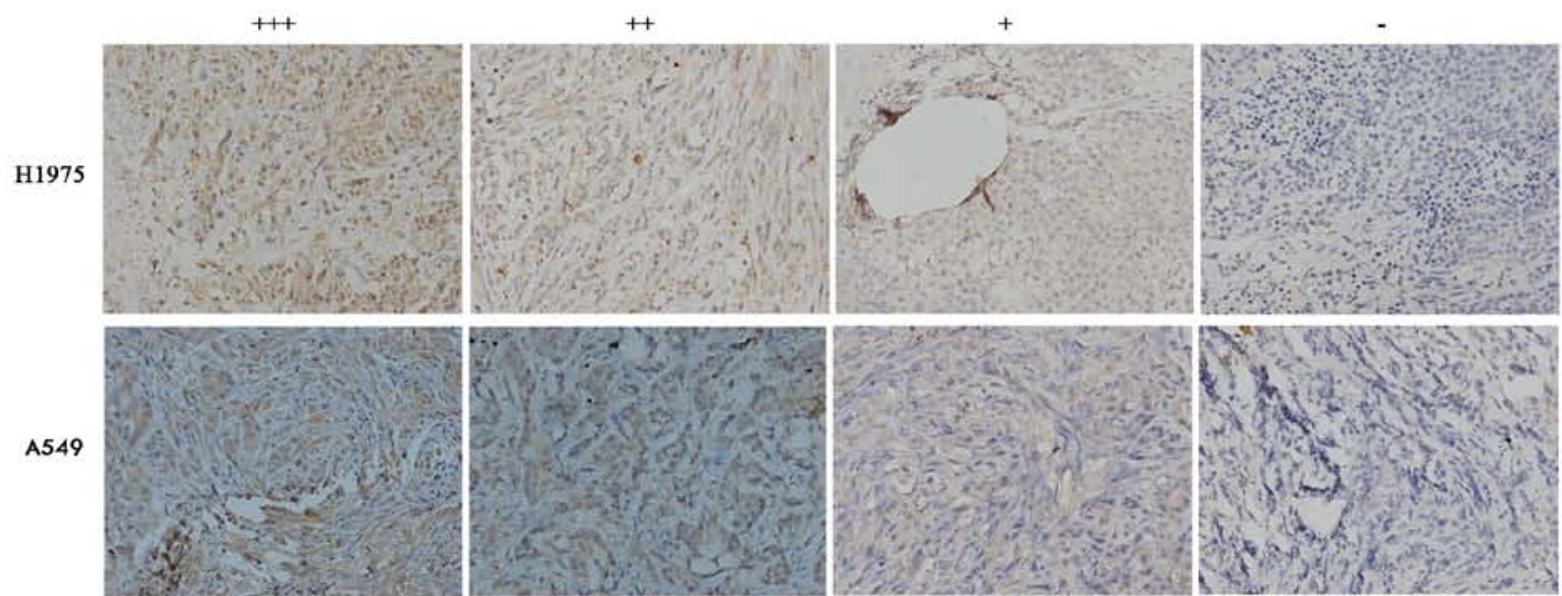

Figure 7. BFD reduces PD-L1, IL-10 and CD206 protein expression in vivo. (A) The administration of BFD resulted in a downregulation of PD-L1, IL-10 and CD206 protein expression in A549 and H1975 tumor tissue dose-dependently. (B) The serum level of IL-10 were significantly lower BFD dose-dependently. (C) Representative IHC staining of PD-L1 and IL-10, ${ }^{*} \mathrm{p}<0.05,{ }^{* * *} \mathrm{p}<0.01,{ }^{* * *} \mathrm{p}<0.001$. 
to its receptor PD-1, which is mainly expressed in activated $\mathrm{T}$ cells, $\mathrm{PD}-\mathrm{L} 1$ induces apoptosis, anergy, unresponsiveness, and exhaustion of $\mathrm{T}$ cells $(41,42)$. We detected that the expression of PD-L1 was significantly increased in NSCLC cells when cocultured with TAMs (p<0.001) (Fig. 4A and B). Prior research has shown that PD-L1 expression was upregulated in HCC cells by macrophages. They also found a significant correlation between PD-L1 expression and TAM infiltration in $63 \mathrm{HCC}$ tissues samples (43). Also, if we suppose some cytokines released from TAMs induced the overexpression of PD-L1 in cancer cells and activated relevant signal pathway. In order to find the target cytokine in TAM-CM, TAM-CM was replaced with rhIL-10 or TAM-CM with neutralizing mAbs against IL-10 in the culture system. The results showed that the expression of PD-L1 in cancer cells was related to the level of IL-10 in the culture system (Fig. 4C and D). It was probably IL-10 secreted by TAMs that regulated the expression of PD-L1 in tumor cells. Some studies showed that PD-L1 expression in tumor infiltrative macrophages could be upregulated through modulation of IL-10 autocrine/ paracrine signaling in gliomas and HCC, leading to macrophages with immunosuppressive phenotype $(27,44)$. We found the correlation between IL-10 secreted by TAMs and PD-L1 in NSCLC cells. Geng and colleagues (34) indicated that tumor-associated PD-L1 expression was correlated with IL-10 products in 40 pancreatic carcinoma samples. Moreover, they also found PD-L1 expression was significantly associated with poor tumor differentiation $(\mathrm{p}<0.01)$ and advanced tumor stage $(\mathrm{p}<0.01)$. Kuang et al $(27)$ found that IL-10 regulated the PD-L1 expression in macrophages of hepatoma tissue, which was similar to our results. To the best of our knowledge, this study is the first to demonstrate the association between PD-L1 in cancer cells and IL-10 secreted by TAMs in NSCLC.

When NSCLC cells were treated with different doses of BFD, the expression of PD-L1 and IL-10 induced by TAMs was gradually inhibited in vitro, and the difference was statistically significant (Fig. 5). In addition, the administration of BFD resulted in a reduction in the expression of PD-L1, IL-10 and CD206 in tumor tissues (Fig. 7A). Overexpression of PD-L1 has been reported to correlate with poor prognosis in a number of human cancers, including breast cancer, kidney cancer, and NSCLCs (45). Blocking PD-L1 with a specific antibody improved specific T cell immunity, suggesting that PD-L1 limits the capacity of $\mathrm{T}$ cells to eliminate tumor cells (46). The concentration of IL-10 in serum of xenograft mice was significantly decreased BFD dose-dependently (Fig. 7B). High IL-10 level in serum or tumors was associated with worse survival in lung cancer patients (47). High level of IL-10 secreted from TAMs was correlated with late stage (stage II, III and IV), lymph node metastases, pleural invasion, lymphovascular invasion and poor differentiation in NSCLC patients (39). Consistent with our in vitro results, these results in vivo suggested that $\mathrm{BFD}$ successfully interrupted the interaction between tumor cells and TAMs by inhibiting the expression of IL-10 and PD-L1.

In our study, we constructed BFD with six kinds of single Chinese herbs in different proportions. Thus, it is highly probable that one or more of these compounds inhibited the activities of PD-L1 and IL-10. For example, as one of BFD components, Milkvetch root is a good immunomodulator (48-50). Milkvetch root suppresses the production of oxygen free radicals to reduce damage to the biomembrane (51). It also could regulate T-lymphocyte function, inhibit NF- $\kappa \mathrm{B}$ activation, and control clinical symptoms in patients with lung cancer. We focused on the BFD regulation of immunosuppression in this investigation to explain its antitumor mechanism. Its antitumor effect is probably through downregulating the expression of PD-L1 and IL-10 in tumor environment of TAMs.

Our results found that BFD groups had no influence on body weight during the whole therapy (Fig. 6), but its long-term administration still needs further study. Besides, as a classic compound of TCM, BFD is probably a multitargeted antitumor drug, proteomics may be helpful to find more target proteins of the drug action. Going further into the antitumor mechanism with proteomics is of great significance in the future. However, the validation by western blotting is required subsequently to proteomics. Pharmaceutical analysis in BFD extract is required in future study. In order to make our research comprehensive, we are currently conducting related clinical trials of BFD.

In conclusion, the authors showed that TAMs play an important role in tumor progression of NSCLC, which was associated with tumor proliferation, migration, invasion and immunosuppression. Moreover, the antitumor mechanism of BFD is related to interruption of the link between TAMs and cancer cells by inhibiting the expression of IL-10 and PD-L1 in vitro and in vivo. Our results demonstrated BFD's potential as a novel treatment for NSCLC.

\section{Acknowledgements}

The authors would like to acknowledge Huirong Ding for his help with flow cytometry, Bin Dong for her help with IHC staining and Guo An for her help with animal experiment at the Central Laboratory of Peking University Cancer Hospital and Institute.

\section{References}

1. Torre LA, Bray F, Siegel RL, Ferlay J, Lortet-Tieulent J and Jemal A: Global cancer statistics, 2012. CA Cancer J Clin 65: 87-108, 2015.

2. Howlader N, Noone AM, Krapcho M, Miler D, Bishop K, Altekruse SF, Kosary CL, Yu M, Ruhl J, Tatalovich Z, et al (eds): SEER Cancer Statistics Review, 1975-2013, National Cancer Institute. Bethesda, MD, seer.cancer.gov/csr/1975_2013/ (based on November 2015 SEER data submission, posted to the SEER web site, April 2016).

3. Miller KD, Siegel RL, Lin CC, Mariotto AB, Kramer JL, Rowland JH, Stein KD, Alteri R and Jemal A: Cancer treatment and survivorship statistics, 2016. CA Cancer J Clin 66: 271-289, 2016.

4. Gardiner RE, Jahangeer S, Forde P, Ariffin AB, Bird B, Soden D and Hinchion J: Low immunogenicity in non-small cell lung cancer; do new developments and novel treatments have a role? Cancer Metastasis Rev 34: 129-144, 2015.

5. Geissmann F, Manz MG, Jung S, Sieweke MH, Merad M and Ley K: Development of monocytes, macrophages, and dendritic cells. Science 327: 656-661, 2010.

6. Solinas G, Germano G, Mantovani A and Allavena P: Tumorassociated macrophages (TAM) as major players of the cancer-related inflammation. J Leukoc Biol 86: 1065-1073, 2009. 
7. Taniguchi K, Hikiji H, Okinaga T, Hashidate-Yoshida T, Shindou H, Ariyoshi W, Shimizu T, Tominaga K and Nishihara T: Essential role of lysophosphatidylcholine acyltransferase 3 in the induction of macrophage polarization in PMA-treated U937 cells. J Cell Biochem 116: 2840-2848, 2015.

8. Coffelt SB, Hughes R and Lewis CE: Tumor-associated macrophages: Effectors of angiogenesis and tumor progression. Biochim Biophys Acta 1796: 11-18, 2009.

9. Zwadlo G, Voegeli R, Schulze Osthoff K and Sorg C: A monoclonal antibody to a novel differentiation antigen on human macrophages associated with the down-regulatory phase of the inflammatory process. Exp Cell Biol 55: 295-304, 1987.

10. Lee JH, Lee GT, Woo SH, Ha YS, Kwon SJ, Kim WJ and Kim IY: BMP-6 in renal cell carcinoma promotes tumor proliferation through IL-10-dependent M2 polarization of tumor-associated macrophages. Cancer Res 73: 3604-3614, 2013.

11. Liu C-Y, Xu J-Y, Shi X-Y, Huang W, Ruan T-Y, Xie P and Ding J-L: M2-polarized tumor-associated macrophages promoted epithelial-mesenchymal transition in pancreatic cancer cells, partially through TLR4/IL-10 signaling pathway. Lab Invest 93: 844-854, 2013.

12. Wang R, Zhang J, Chen S, Lu M, Luo X, Yao S, Liu S, Qin Y and Chen H: Tumor-associated macrophages provide a suitable microenvironment for non-small lung cancer invasion and progression. Lung Cancer 74: 188-196, 2011.

13. Tjiu JW, Chen JS, Shun CT, Lin SJ, Liao YH, Chu CY, Tsai TF, Chiu HC, Dai YS, Inoue H, et al: Tumor-associated macrophageinduced invasion and angiogenesis of human basal cell carcinoma cells by cyclooxygenase-2 induction. J Invest Dermatol 129 : 1016-1025, 2009.

14. Li CC, Hou YC, Yeh CL and Yeh SL: Effects of eicosapentaenoic acid and docosahexaenoic acid on prostate cancer cell migration and invasion induced by tumor-associated macrophages. PLoS One 9: e99630, 2014.

15. Condeelis $\mathbf{J}$ and Pollard JW: Macrophages: Obligate partners for tumor cell migration, invasion, and metastasis. Cell 124 263-266, 2006.

16. Kurahara H, Shinchi H, Mataki Y, Maemura K, Noma H, Kubo F, Sakoda M, Ueno S, Natsugoe S and Takao S: Significance of M2-polarized tumor-associated macrophage in pancreatic cancer. J Surg Res 167: e211-e219, 2011

17. Mellor AL and Munn DH: Creating immune privilege: Active local suppression that benefits friends, but protects foes. Nat Rev Immunol 8: 74-80, 2008.

18. Fan Q-M, Jing Y-Y, Yu GF, Kou XR, Ye F, Gao L, Li R, Zhao QD, Yang Y, Lu ZH, et al: Tumor-associated macrophages promote cancer stem cell-like properties via transforming growth factor-betal-induced epithelial-mesenchymal transition in hepatocellular carcinoma. Cancer Lett 352: 160-168, 2014.

19. Pollard JW: Tumour-educated macrophages promote tumour progression and metastasis. Nat Rev Cancer 4: 71-78, 2004.

20. Lin EY, Nguyen AV, Russell RG and Pollard JW: Colonystimulating factor 1 promotes progression of mammary tumors to malignancy. J Exp Med 193: 727-740, 2001.

21. Laoui D, Van Overmeire E, De Baetselier P, Van Ginderachter JA and Raes G: Functional relationship between tumor-associated macrophages and macrophage colony-stimulating factor as contributors to cancer progression. Front Immunol 5: 489, 2014.

22. Robinson SC, Scott KA, Wilson JL, Thompson RG, Proudfoot AE and Balkwill FR: A chemokine receptor antagonist inhibits experimental breast tumor growth. Cancer Res 63: 8360-8365, 2003.

23. Whitehurst B, Flister MJ, Bagaitkar J, Volk L, Bivens CM, Pickett B, Castro-Rivera E, Brekken RA, Gerard RD and Ran S: Anti-VEGF-A therapy reduces lymphatic vessel density and expression of VEGFR-3 in an orthotopic breast tumor model. Int J Cancer 121: 2181-2191, 2007.

24. Dineen SP, Lynn KD, Holloway SE, Miller AF, Sullivan JP, Shames DS, Beck AW, Barnett CC, Fleming JB and Brekken RA: Vascular endothelial growth factor receptor 2 mediates macrophage infiltration into orthotopic pancreatic tumors in mice. Cancer Res 68: 4340-4346, 2008.

25. Rauh MJ, Sly LM, Kalesnikoff J, Hughes MR, Cao LP, Lam V and Krystal G: The role of SHIP1 in macrophage programming and activation. Biochem Soc Trans 32: 785-788, 2004.

26. Torisu-Itakura H, Lee JH, Huynh Y, Ye X, Essner R and Morton DL: Monocyte-derived IL-10 expression predicts prognosis of stage IV melanoma patients. J Immunother 30: 831-838, 2007
27. Kuang DM, Zhao Q, Peng C, Xu J, Zhang JP, Wu C and Zheng L: Activated monocytes in peritumoral stroma of hepatocellular carcinoma foster immune privilege and disease progression through PD-L1. J Exp Med 206: 1327-1337, 2009.

28. Xia Y, Wang Y, Yang J and Song K: Study on effects of Bufei Decoction on $\alpha$-SMA in lung tissue of pulmonary fibrosis rats. Zhonghua Zhongyiyao Xuekan 23: 1916-1918, 2014 (In Chinese).

29. Zhang H, Xia YL, Yang J and Song K: Study on effects of Bufei Decoction on MMP-9 and TIMP-1 in lung tissue of pulmonary fibrosis rats. Zhonghua Zhongyiyao Xuekan 29: 2673-2679, 2011

30. Du X, Du X, Zhang K, Wang J, Guo G and Wang R: The clinical trials to observe the effect of Astragalus injection combine with chemotherapy in patients with malignant tumor. Shanghai Med Pharm J 2: 16, 2010.

31. Chiu PY, Lam PY, Yan CW and Ko KM: Schisandrin B protects against solar irradiation-induced oxidative injury in BJ human fibroblasts. Fitoterapia 82: 682-691, 2011.

32. Chi D and Huang Q: The effect of Fructus schisandrae B element to vascular endothelial growth factor in human glioma. (PhD thesis). Southern Medical University, Guangzhou, 2008 (In Chinese).

33. Reagan-Shaw S, Nihal M and Ahmad N: Dose translation from animal to human studies revisited. FASEB J 22: 659-661, 2008.

34. Geng L, Huang D, Liu J, Qian Y, Deng J, Li D, Hu Z, Zhang J, Jiang $\mathrm{G}$ and Zheng S: B7-H1 up-regulated expression in human pancreatic carcinoma tissue associates with tumor progression. J Cancer Res Clin Oncol 134: 1021-1027, 2008.

35. Ostuni R, Kratochvill F, Murray PJ and Natoli G: Macrophages and cancer: From mechanisms to therapeutic implications. Trends Immunol 36: 229-239, 2015.

36. Chen C, Shen Y, Qu QX, Chen XQ, Zhang XG and Huang JA: Induced expression of B7-H3 on the lung cancer cells and macrophages suppresses T-cell mediating anti-tumor immune response. Exp Cell Res 319: 96-102, 2013.

37. Lei H, Ju DW, Yu Y, Tao Q, Chen G, Gu S, Hamada H and Cao X: Induction of potent antitumor response by vaccination with tumor lysate-pulsed macrophages engineered to secrete macrophage colony-stimulating factor and interferon- $\gamma$. Gene Ther 7: 707-713, 2000 .

38. Salazar-Onfray F: Interleukin-10: A cytokine used by tumors to escape immunosurveillance. Med Oncol 16: 86-94, 1999.

39. Wang R, Lu M, Zhang J, Chen S, Luo X, Qin Y and Chen H: Increased IL-10 mRNA expression in tumor-associated macrophage correlated with late stage of lung cancer. J Exp Clin Cancer Res 30: 62, 2011

40. Lee SJ, Jang BC, Lee SW, Yang YI, Suh SI, Park YM, Oh S, Shin JG, Yao $\mathrm{S}$, Chen L, et al: Interferon regulatory factor-1 is prerequisite to the constitutive expression and IFN-gamma-induced upregulation of B7-H1 (CD274). FEBS Lett 580: 755-762, 2006.

41. Dong H, Strome SE, Salomao DR, Tamura H, Hirano F, Flies DB, Roche PC, Lu J, Zhu G, Tamada K, et al: Tumor-associated B7-H1 promotes T-cell apoptosis: A potential mechanism of immune evasion. Nat Med 8: 793-800, 2002.

42. Barber DL, Wherry EJ, Masopust D, Zhu B, Allison JP, Sharpe AH, Freeman GJ and Ahmed R: Restoring function in exhausted CD8 T cells during chronic viral infection. Nature 439: 682-687, 2006.

43. Chen J, Li G, Meng H, Fan Y, Song Y, Wang S, Zhu F, Guo C, Zhang L and Shi Y: Upregulation of B7-H1 expression is associated with macrophage infiltration in hepatocellular carcinomas. Cancer Immunol Immunother 61: 101-108, 2012.

44. Bloch O, Crane CA, Kaur R, Safaee M, Rutkowski MJ and Parsa AT: Gliomas promote immunosuppression through induction of B7-H1 expression in tumor-associated macrophages. Clin Cancer Res 19: 3165-3175, 2013.

45. Velcheti V, Schalper KA, Carvajal DE, Anagnostou VK, Syrigos KN, Sznol M, Herbst RS, Gettinger SN, Chen LP and Rimm DL: Programmed death ligand-1 expression in non-small cell lung cancer. Lab Invest 94: 107-116, 2014.

46. Chanmee T, Ontong P, Konno K and Itano N: Tumor-associated macrophages as major players in the tumor microenvironment. Cancers (Basel) 6: 1670-1690, 2014.

47. Hatanaka H, Abe Y, Kamiya T, Morino F, Nagata J, Tokunaga T, Oshika Y, Suemizu H, Kijima H, Tsuchida T, et al: Clinical implications of interleukin (IL)-10 induced by non-small-cell lung cancer. Ann Oncol 11: 815-819, 2000.

48. Jin M, Zhao K, Huang Q and Shang P: Structural features and biological activities of the polysaccharides from Astragalus membranaceus. Int J Biol Macromol 64: 257-266, 2014. 
49. Li W, Sun YN, Yan XT, Yang SY, Song SB, Lee YM and Kim YH: NF- $\kappa$ B inhibitory activity of sucrose fatty acid esters and related constituents from Astragalus membranaceus. J Agric Food Chem 61: 7081-7088, 2013.

50. Chen X, May B, Di YM, Zhang AL, Lu C, Xue CC and Lin L: Oral Chinese herbal medicine combined with pharmacotherapy for stable COPD: A systematic review of effect on BODE index and six minute walk test. PLoS One 9: e91830, 2014.

51. Wang T, Sun Y, Jin L, Xu Y, Wang L, Ren T and Wang K: Enhancement of non-specific immune response in sea cucumber (Apostichopus japonicus) by Astragalus membranaceus and its polysaccharides. Fish Shellfish Immunol 27: 757-762, 2009. 